\title{
Flow among higher education teachers: A job demands-resources perspective
}

\author{
Katarina Habe ${ }^{1}$ and Sara Tement ${ }^{2}$ \\ ${ }^{1}$ Department of Basic Pedagogical Studies, Faculty of Education, University of Maribor, Slovenia \\ ${ }^{2}$ Department of Psychology, Faculty of Arts, University of Maribor, Slovenia
}

\begin{abstract}
The aim of the present study was to investigate job resources and demands and their relatedness to work flow. In line with the three-dimensional model of flow, absorption, work enjoyment and intrinsic work motivation were explored as separate outcomes. Our predictions were tested using a sample of 293 higher education teachers in Slovenia. The participants indicated their levels of flow, job demands (e.g., workload) and job resources (e.g., variety and autonomy) using the Slovenian version of the work flow inventory and job demands-resources scales. Our hypotheses were tested using moderated multiple regression where main as well as interactive effects between job resources and demands were examined. Autonomy and variety were found to enhance absorption, work enjoyment and intrinsic work motivation. Furthermore, autonomy was found to be the most important predictor of all the work flow dimensions. In contrast, workload was not significantly related to any of the outcomes. We also found interactive effects of variety and workload as well as variety and autonomy on absorption.
\end{abstract}

Keywords: work flow, job resources, job demands, higher education teachers

\section{Zanos pri visokošolskih učiteljih z vidika delovnih zahtev in delovnih virov}

\author{
Katarina Habe ${ }^{1}$ in Sara Tement ${ }^{2}$ \\ ${ }^{1}$ Oddelek za temeljne pedagoške predmete, Pedagoška fakulteta, Univerza v Mariboru \\ ${ }^{2}$ Oddelek za psihologijo, Filozofska fakulteta, Univerza v Mariboru
}

\begin{abstract}
Povzetek: Namen naše raziskave je bil raziskati delovne vire in zahteve ter njihovo povezanost z zanosom pri delu. V skladu s tridimenzionalnim modelom zanosa smo proučevali zatopljenost, zadovoljstvo pri delu in notranjo motivacijo na delovnem mestu kot ločene dimenzije. Vzorec je zajemal 293 visokošolskih učiteljev po Sloveniji. Udeleženci so ocenjevali stopnjo delovnega zanosa, delovnih zahtev (npr. splošne delovne obremenitve) in delovnih virov (npr. raznolikost in avtonomija) s pomočjo slovenske različice Vprašalnika o zanosu pri delu in Lestvice delovnih zahtev/ virov. Hipoteze so bile preverjene s pomočjo multiple regresije, pri čemer smo preučevali glavni in interaktivni učinek delovnih virov in zahtev. Rezultati so pokazali, da sta avtonomija in raznolikost pozitivno povezani z zatopljenostjo, zadovoljstvom na delovnem mestu in notranjo motivacijo pri delu. Ugotovili smo tudi, da je avtonomija najpomembnejši napovednik vseh treh dimenzij zanosa pri delu. Po drugi strani delovna obremenitev ni bila povezana z nobeno od dimenzij zanosa pri delu. Potrjen je bil tudi interaktivni učinek raznolikosti in delovne obremenitve ter raznolikosti in avtonomije na zatopljenost pri delu.
\end{abstract}

Ključne besede: delovni zanos, delovne zahteve in delovni viri, visokošolski učitelji

\footnotetext{
*Naslov/Address: Katarina Habe, Oddelek za temeljne pedagoške predmete, Pedagoška fakulteta, Univerza v Mariboru, Koroška cesta 160, 2000 Maribor; Oddelek za glasbeno pedagogiko, Akademija za glasbo, Univerza v Ljubljani, Stari Trg 34, 1000 Ljubljana, e-pošta: habekatarina@gmail.com
}

Članek je licenciran pod pogoji Creative Commons Attribution 4.0 International licence (CC-BY licenca). The article is licensed under a Creative Commons Attribution 4.0 International License (CC-BY license). 
According to Csíkszentmihályi (2002), flow is the mental state of operation in which a person is fully immersed in a feeling of energized focus, full involvement and success in the process of an activity. Flow is a kind of optimal experience which depends mainly on subjective evaluations of what the possibilities for action are, and of one's own capacities. He further pointed out that when a person is in flow he/she feels in control of his/her own actions, and masters his/her own fate. Jackson and Csíkszentmihályi (1999) identified nine core dimensions of flow: (1) challengeskill balance, (2) action-awareness merging, (3) clear goals, (4) clear feedback, (5) concentration, (6) sense of control, (7) loss of self-consciousness, (8) transformation of time, (9) autotelic experience. Quinn (2005) argued that these dimensions should be separated into antecedents (goal clarity, challenge-skill balance, concentration and feedback clarity) and consequences (sense of control and autotelic experience). Thus, several flow dimensions may actually be conditions which facilitate flow. Such conditions should in turn be systematically examined. Furthermore, conditions of flow play an extremely important role in the workplace, as they lead to higher productivity, innovation and employee development. In fact, Csíkszentmihályi (2002) argued that people report flow mostly in the work context, whereas flow in leisure is relatively scarce. Although other researchers have identified flow experiences during many different activities, including sports (Jackson, Kimiecik, Ford, \& Marsh, 1998), hobbies (Csíkszentmihályi, 2002) and music performance (O'Neill, 1999), work-related flow may actually be the most pronounced (Bakker, 2005).

Based on the previous deliberations, the present study was aimed at examining the antecedents of work-related flow. We claim that resourceful working conditions (i.e., job resources) positively relate to flow, whereas demanding working conditions (i.e., job demands) diminish flow in general. Second, we investigated whether job resources and job demands predict flow additively and interactively. We propose that resourceful working conditions themselves may not be enough to predict flow. Interactions between job resources and demands may offer an answer on flowfacilitating conditions.

\section{Job resources, job demands and work flow}

According to the job demands-resources model (JDR; Bakker \& Demerouti, 2007), which was the theoretical ground point of our research, job resources help a person to cope with job demands, increase learning and development, and are supposedly useful in achieving work-related goals. They may be located at the level of the organization (e.g., pay), may be embedded in social relations (e.g., support) or may derive from the work (and work tasks) itself (e.g., skill variety, autonomy) (Bakker \& Demerouti, 2007). Especially, resources located at the task level have motivational potential because they enhance meaningfulness of work and hold employees responsible for work processes and outcomes (Hackman \& Oldham, 1975). In contrast to pay, which may be related to extrinsic motivation, resources located at tasks level are more likely to foster intrinsic motivation (e.g.,
Hackman \& Oldham, 1975). In fact, previous studies found that job resources at task level are primarily positively linked to motivational processes such as higher work engagement at work (e.g., Bakker \& Demerouti, 2008). Therefore, our study is focused on resources which derive from work tasks only (more precisely, autonomy and variety).

The JD-R model, however, does not make specific claims over why one type of resource may be more important than the other. According to Karasek $(1979,1998)$, job decision latitude which encompasses autonomy in work-related decisions and variety in skills used in work tasks is the most central job resource. In his demand-control model (DCM; Karasek, 1979, 1998), decision latitude (i.e., the combined effects of autonomy and variety) is assumed to have a crucial role in buffering demanding job aspects and promoting positive outcomes such a motivation or job satisfaction. Similarly, Csíkszentmihályi (2002) considered the sense of control as an important element promoting flow. Autonomy or employees' freedom in scheduling their work and in determining work methods has repeatedly been found to increase positive affect (e.g., Saavedra and Kwun, 2000) and motivation (Fried $\&$ Ferris, 1987). Bakker (2005) showed that autonomy and opportunities for self-growth are related to each of the three flow components. Similar findings may pertain also to variety (Demerouti, 2006). According to Demerouti (2006), skill variety as conceived by Hackman and Oldham (1975) is even a far better antecedent of work flow than the balance between challenges and skills suggested by Csíkzentmihályi (2002). Skill variety represents a diversity of work activities that require different skills and talents from the employee, all of which are conditions enhancing flow.

\section{Work flow among teachers}

Bakker (2005) defines work flow as a short-term peak experience at work that is characterized by absorption, work enjoyment and intrinsic work motivation. These states can be referred to as the core elements of the flow experience (Bakker, 2005). Absorption refers to total concentration and immersion in the activity. Work enjoyment indicates a very positive judgment about the quality of working life. Intrinsic motivation refers to the need to perform a certain work-related activity with the aim of experiencing inherent pleasure and satisfaction in the activity (Bakker, 2005; Deci \& Ryan, 1985). Although one can report high experiences on all three dimensions of work flow (Bakker, 2008), it may be interesting to explore whether each of these conditions has its own unique antecedents.

A handful of studies to date examined the antecedents of work flow (e.g., Bakker, 2005; Fagerlind, Gustavsson, Johansson, \& Ekberg, 2013; Salanova, Bakker, \& Llorens, 2006). Even less studies have systematically examined conditions of flow among teachers, specifically higher education teachers (Beard \& Hoy, 2010). For instance, Bakker (2005) found that job resources, including autonomy, performance feedback, social support and supervisory coaching, have a positive influence on the balance between teachers' challenges and skills, which, in turn, contributes to their experience of flow (absorption, work enjoyment and intrinsic work motivation). In addition, Salanova et al. (2006) 
found reciprocal relations between personal resources (i.e., self-efficacy beliefs), organizational resources (including social support, climate and clear goals) and work-related flow in a two-wave study among secondary school teachers.

Based on these empirical findings about job resources we formulated the following hypotheses: Autonomy will be positively related to absorption, work enjoyment and intrinsic work motivation (hypothesis 1); Variety will be positively related to absorption, work enjoyment and intrinsic work motivation (hypothesis 2).

Additionally, it may be assumed that job resources may be summed up when predicting flow, reflecting the notion of the motivational potential score (Hackman \& Oldham, 1975). Thus, having more job resources available is better than having only one job resource available. Higher autonomy and higher variety may therefore jointly predict even higher levels of work-related flow. Therefore, on a more explorative note, we assumed that autonomy will moderate the relationship between variety and absorption, work enjoyment and intrinsic work motivation. In the condition of high autonomy, greater variety levels will increase all three dimensions of work flow (hypothesis 3).

In contrast to job resources, "job demands refer to those physical, psychological, social, or organizational aspects of the job that require sustained physical and/or psychological (cognitive and emotional) effort or skills and are therefore associated with certain physiological and/or psychological costs" (Bakker \& Demerouti, 2007; p. 312). We argue that decreased levels of work flow at work can be seen as one of the costs of high job demands. Although job demands such as workload may be primarily associated with ill health (Bakker \& Demerouti, 2007), several studies have confirmed that high workload may also detract from positive psychological functioning (e.g., Halbesleben, 2010). Our study focused on workload in particular, as it may be a central job demand according to the demand-control model (DCM; Karasek, 1979, 1998). Thus, we further assumed that workload will be negatively related to absorption, work enjoyment and intrinsic work motivation (hypothesis 4).

Another central assumption of the JD-R model involves the interactions between job demands and resources (Bakker $\&$ Demerouti, 2008). Studies have found that job resources particularly influence motivation-related job outcomes such as work engagement when job demands are high (Bakker, Hakanen, Demerouti, \& Xanthopoulou, 2007). As work engagement may be seen as a positive long-term experience at work, a similar reasoning can be applied for positive shortterm experiences such as flow. In other words, resources may be particularly important for enhancing flow when the working conditions are especially demanding, whereas they may not be that valued in their own right. Such a notion is also consistent with Karasek's conceptualization (1979) of "active jobs", where both the challenge of job demands and high job decision latitude (i.e., autonomy and variety) are present. Such jobs are associated with on-job as well as off-job personal development and are, for instance, related to higher job satisfaction and reduced depression. Further support this line of reasoning, Fagerlind et al. (2013) found a higher likelihood of experiencing work flow in active jobs in different organizations. We argue that similar interactive effect may also be assumed among university teachers. Thus, it can be proposed that workload will moderate the relationship between variety and absorption, work enjoyment and intrinsic work motivation. In the condition of high workload, greater variety levels will increase all three dimensions of work flow (hypothesis 5). Furthermore, workload will moderate the relationship between autonomy and absorption, work enjoyment and intrinsic work motivation. In the condition of high workload, greater autonomy levels will increase all three dimensions of work flow (hypothesis 6).

\section{Method}

\section{Sample and procedure}

The participants in the present study were higher education teachers who responded to an online survey. The participants received an invitation letter explaining the aim of the study and a link to the questionnaire via their faculty email address. Contact persons at faculties from each university sent out the emails to the mailing list including all higher education teachers employed at a particular faculty. The online survey was available for two weeks with an email reminder in between.

A total of 293 higher education teachers filled out the questionnaire. The participants, $46.8 \%$ of whom were female, were from all three public Slovenian universities (University of Maribor: 47.4\%; University of Ljubljana: 39.6\%; University of Primorska: $13.0 \%$ ). Despite the use of a reminder and a personalized description of the study, response rates at all three universities (University of Maribor: 15.9\%; University of Ljubljana: 4.2\%; University of Primorska: 11.4\%) were lower to those found in other research using email surveys $(M=34.6 \%$; $S D=15.7 \%$; Cook, Heath, \& Thompson, 2000); The sample consisted of instructors (37.1\%), assistant professors (32.1\%), associate professors (17.1\%) and full professors $(13.7 \%)$ who worked in the fields of social sciences (31.7\%), natural sciences $(29.0 \%)$, technological sciences/ engineering $(21.5 \%)$ and others $(17.8 \%) .11 .3 \%$ of the teachers were 20 to 30 years old, $40.6 \%$ were between 30 and 40 , $21.5 \%$ were between 40 and 50 , and $26.6 \%$ were older than 50. The university teachers spent $3.13(S D=2.42)$ hours a day on their research activities and $4.03(S D=3.37)$ on their teaching obligations on average. The average job tenure was 12.97 years $(S D=9.50)$.

\section{Instruments}

Job demands. Workload was used as an indicator of job demands. The measure was adapted from the Perceived Work Demand Scale (Boyar, Carr, Mosley, \& Carson, 2007). The five-item scale measured the extent to which one perceived one's job as stressful and burdensome using a five-point Likert scale ( $1=$ strongly disagree, $5=$ strongly agree). An item example is "I feel like I have a lot of work demands". The Cronbach's alpha in previous studies was between .88 and .90 (Košir, Licardo, Tement \& Habe, 2014; Tement and Korunka, 2013). 
Job resources. Two different scales (i.e., autonomy and variety) were used as indicators of job resources. The scales were self-constructed according to well-established scales (e.g., Karasek et al., 1998). Both scales have a five-point Likert answering scale ( 1 = strongly disagree, $5=$ strongly agree). Autonomy was assessed using a three-item scale. Participants indicated the level to which their jobs allow them to decide on how and when to perform work tasks. An example is "My job allows me to make decisions on my own". The Cronbach's alpha in previous studies was between .76 and .79 (Košir \& Kos Strašek, 2014; Košir, Licardo, Tement \& Habe, 2014; Tement \& Korunka, 2013). Due to low reliability of the original three item scale, variety or the scope of skills utilized during work was tapped using the item "My job requires learning new things". Although one-item measures can be potentially problematic, they were found to appropriately address several work-related constructs (Wanous \& Hudy, 2001; Wanous, Reichers \& Hudy, 1997).

Work flow. The work-related flow inventory (WOLF) by Bakker (2008) was used to measure flow experiences specific to the work context. The 13-item scale includes the dimensions absorption (four items), work enjoyment (four items) and intrinsic work motivation (five items). Respondents indicated the level of work-related flow experiences on a seven-point frequency scale $(1=$ never, $7=$ always $)$. Example items are "I get carried away by my work", "I do my work with a lot of enjoyment" and "I get my motivation from the work itself and not from the reward for it". We performed a translation into the Slovenian language and a back translation for the accuracy check. The original version of WOLF exhibits appropriate reliability, and factorial as well construct validity (Bakker, 2008).

Control variables. As gender, academic rank and age may also play a role in work-related flow, we controlled for these variables in the present study. Gender was labeled $0=$ male and $1=$ female. Academic rank was dichotomized, with the label 0 reflecting assistant professors and lower ranks, whereas 1 reflected associate professors and full professors. Age was dichotomized as well. Age groups under 40 years were labeled with 0 , while those 40 years and above were labeled with 1 .

\section{Analyses}

First, we established the factorial validity of the Slovenian version of the work-related flow scale following the common procedures (Bakker, 2008). We conducted a set of confirmatory factor analyses (AMOS 18) to determine whether the Slovenian work-related flow scale exhibits similar psychometric properties to the original version. The traditional chi-square statistic (and the ratio between chisquare and degrees of freedom; $\left.\chi^{2} / d f\right)$, the Goodness-of-Fit Index (GFI), the Comparative Fit Index (CFI) and the Root Mean Square Error of Approximation (RMSEA) were used as indicators of model fit. According to recommendations, the $\chi^{2 / d f}$ ratio should be 2:1 for appropriate fit, whereas the GFI and CFI values should be .90 and higher (Brown, 2006; McDonald and Ho, 2002). The RMSEA, on the other hand, should be at least lower than 08 .

Our hypotheses were tested using hierarchical moderated regression for all three work-related flow dimensions separately. In step 1, we entered the control variables, followed by job demands and resources in step 2 . In the last step, we entered the three multiplicative terms of job demands and resources to determine whether job demands and resources predict work-related flow additively and interactively. In addition, we also examined whether the two job resources interact while predicting work-related flow. Based on Aiken and West (1991), we plotted the significant interaction terms. We also controlled for the common Type II error in moderated multiple regression (Aguinis, 1995). Therefore, the significance level was adjusted to $p<.10$ for interaction terms only (Aryee, Srinivas, \& Tan, 2005).

\section{Results}

\section{Preliminary analyses}

In following the approach of Bakker (2008), we ran a confirmatory factor analysis on WOLF where several competing models were tested against each other. A threefactor model, where absorption, work enjoyment and intrinsic work motivation were represented as separate factors, was compared to three two-factor models (including all possible combinations where items from two dimensions were collapsed into a single factor) and a one-factor model (with all items loading on a single factor). The fit indices in Table 1 show that the three-factor model was superior to the three two-factor models and the one-factor model. Chi-square difference tests have also shown that the three-factor model fits the data significantly better than competing models. However, the three-factor model could still be improved as suggested by the modification indices. In a revised model, we allowed three error terms which had overlapping content to correlate (e.g. "I feel happy during my work" and "I feel cheerful when I am working"). The revised three-factor model fits the data clearly better than other models. The adequacy of the revised three-factor model was also confirmed by appropriate factor loadings on the respective factors (all loadings were larger than 0.52). Inspection of the modification indices did not reveal any salient cross-loadings either. Therefore, it can be concluded that the Slovenian version of WOLF exhibits a desired factorial validity.

As our variables are based on self-reports only, two approaches were utilized to test common method bias (CMB). First, a Harman's single-factor test by using exploratory factor analyses was conducted. As 5 factors could be identified in principal components analysis and the first factor explained $38 \%$ of the overall variance, CMB may not be great concern. In addition, a set of confirmatory factor analyses was conducted to further test whether all scales can be empirically distinguished. The assumed 6 -factor model provided reasonable fit to the data (model fit: $\chi^{2}(198)=439.40$, $\mathrm{CFI}=.94, \mathrm{GFI}=.88, \mathrm{RMSEA}=.066)$.

\section{Regression analyses}

Table 2 presents means, standard deviations, Cronbach's alphas and correlations between all constructs of interest. The proposed relations between job resources (i.e., autonomy and variety) and the work-related flow dimensions were generally confirmed. More precisely, autonomy and variety were 
Table 1. CFA fit indices for competing models of work-related flow

\begin{tabular}{|c|c|c|c|c|c|c|c|}
\hline Model & $\chi^{2}$ & $d f$ & GFI & CFI & RMSEA & $\Delta \chi^{2}$ & $\Delta d f$ \\
\hline M1: 1-factor model & 474.94 & 65 & .77 & .86 & .15 & & \\
\hline $\begin{array}{l}\text { M2: 2-factor model } \\
\text { (AB+IWM; WE) }\end{array}$ & 364.62 & 64 & .81 & .90 & .13 & M1-M2: $110.32^{* * *}$ & 1 \\
\hline $\begin{array}{l}\text { M3: 2-factor model } \\
(A B+W E ; \text { IWM })\end{array}$ & 412.44 & 64 & .79 & .88 & .14 & M1-M3: $62.50^{* * *}$ & 1 \\
\hline $\begin{array}{l}\text { M4: 2-factor model } \\
\text { (WE+IWM; AB) }\end{array}$ & 298.61 & 64 & .85 & .91 & .11 & M1-M4: $176.33^{* * *}$ & 1 \\
\hline M5: 3-factor model & 218.18 & 62 & .89 & .95 & .09 & M1-M5: $256.76^{* * *}$ & 3 \\
\hline M6: 3-factor model (revised) & 125.88 & 59 & .94 & .98 & .06 & M1-M6: $349.06^{* * *}$ & 6 \\
\hline
\end{tabular}

Note. $\chi^{2}$ - Chi-square statistic; $d f$ - degrees of freedom; GFI - Goodness-of-Fit Index; CFI - Comparative Fit Index; RMSEA - Root Mean Square Error of Approximation; $\Delta \chi^{2}-$ Chi-square difference test; $\mathrm{AB}$ - absorption; WE - work enjoyment; IWM - intrinsic work motivation. ${ }^{* * *} p<.001$

positively related to absorption, work enjoyment and intrinsic work motivation. Interestingly, workload was positively related to absorption, whereas it was not significantly related to the other two work-related flow dimensions. All scales also exhibit reliabilities within the appropriate range.

Table 3 summarizes the results of the hierarchical moderated regression for each work-related flow dimension separately. The results follow a fairly similar pattern for all three dimensions. Among the control variables, entered in step 1, only gender was significantly related to absorption, whereas academic rank was significantly related to intrinsic work motivation. Women and teachers with higher ranks experienced more absorption and intrinsic work motivation, respectively. The variables entered in step 2 explained significant portions of variance in all three work-related flow dimensions. More precisely, autonomy and variety were found to enhance absorption, work enjoyment and intrinsic work motivation, thus supporting $\mathrm{H} 1$ and $\mathrm{H} 2$. In fact, autonomy was found to be the most important predictor of all the workrelated flow dimensions. In contrast to $\mathrm{H} 4$, workload was not significantly related to any of the outcomes.

The interaction terms, entered in the final step, explained only significant portions of absorption, but not work enjoyment and intrinsic work motivation. More precisely, we found interactive effects of variety and workload (Figure 1) as well as variety and autonomy (Figure 2) on absorption. In the first interactive effect, higher variety is related to higher absorption per se. However, in the condition of high autonomy, greater variety levels substantially increased absorption levels. A subsequent simple slopes test further supported this finding (simple slope test for high autonomy, $B=0.74, p<0.001$ ). The positive relation between variety and absorption was less pronounced, however still significant, in the low autonomy condition (simple slope test for low autonomy, $B=0.25, p$ $<0.05)$. Therefore, H3 can be partially supported. A similar finding was obtained for the second interactive effect. Again, higher variety was related to higher absorption regardless of workload levels. However, under conditions of high workload and high variety, feelings of absorption are even more likely to occur. This finding was further supported by a simple slopes test, which revealed a significant positive association between variety and absorption in the high as well as low workload condition (simple slope test for low workload, $B=$ $0.36, p<0.01$; simple slope test for high workload, $B=0.62$, $p<0.001)$. Therefore, H5 can be at least partially supported as well. As we did not find a significant interactive effect involving workload and autonomy, H6 has to be rejected.

Table 2. Means, standard deviations, reliabilities, and correlations between the studied variables

\begin{tabular}{lcccccccccc}
\hline & $M$ & $S D$ & 1 & 2 & 3 & 4 & 5 & 6 & 7 & 8 \\
\hline 1. Gender & 0.47 & 0.50 & $/$ & & & & & & & \\
2. Age & 0.48 & 0.50 & -.05 & $/$ & & & & & \\
3. Academic rank & 0.63 & 0.48 & -.11 & $.38^{* * *}$ & $/$ & & & & \\
4. Workload & 4.26 & 0.60 & $.14^{*}$ & .01 & .11 & $(.80)$ & & & \\
5. Autonomy & 3.79 & 0.78 & $-.14^{*}$ & $.23^{* * *}$ & $.29^{* * *}$ & .02 & $(.78)$ & & & \\
6. Variety & 4.68 & 0.61 & $.13^{*}$ & $.15^{* *}$ & $.16^{* *}$ & $.19^{* *}$ & $.12^{*}$ & $/$ & & \\
7. AB & 5.23 & 1.07 & $.12^{*}$ & $.15^{* *}$ & $.15^{*}$ & $.14^{*}$ & $.32^{* * *}$ & $.29^{* * *}$ & $(.85)$ & \\
8. WE & 4.95 & 1.32 & -.01 & .08 & $.14^{*}$ & .04 & $.37^{* * *}$ & $.28^{* * *}$ & $.66^{* * *}$ & $(.94)$ \\
9. IWM & 4.70 & 1.22 & .03 & $.18^{* *}$ & $.23^{* * *}$ & .05 & $.44^{* * *}$ & $.30^{* * *}$ & $.63^{* * *}$ & $.75^{* * *}$ \\
\hline
\end{tabular}

Note. Alpha reliability coefficients of predictor and outcome measures are shown on the diagonal. AB - absorption; WE - work enjoyment; IWM - intrinsic work motivation; gender $(0=$ male, $1=$ female $)$; age $(0=$ under 40 years; $1=40$ years and above $)$ a academic rank $(0=$ assistant professors and lower ranks; $1=$ associate professors and full professors).

${ }^{*} p<.05,{ }^{* *} p<.01,{ }^{* * *} p<.001$ 
Table 3. Hierarchical moderated regression for variables predicting work-related flow

\begin{tabular}{|c|c|c|c|c|c|c|}
\hline & \multicolumn{6}{|c|}{ Work-related flow } \\
\hline & \multicolumn{2}{|c|}{ Absorption } & \multicolumn{2}{|c|}{ Work enjoyment } & \multicolumn{2}{|c|}{ Intrinsic work motivation } \\
\hline & $B$ & $\beta$ & $B$ & $\beta$ & $B$ & $\beta$ \\
\hline \multicolumn{7}{|l|}{ Step 1: Control variables } \\
\hline Gender & 0.26 & $.12^{*}$ & 0.04 & .02 & 0.15 & .06 \\
\hline Age & 0.22 & .10 & 0.07 & .03 & 0.28 & .11 \\
\hline Academic rank & 0.23 & .10 & 0.33 & .12 & 0.52 & $.21^{* *}$ \\
\hline$\Delta R^{2}$ & & $.04^{* *}$ & & .02 & & $.07^{* * *}$ \\
\hline \multicolumn{7}{|c|}{ Step 2: Job demands and resources } \\
\hline Workload & 0.08 & .05 & -0.12 & -.05 & -0.09 & -.04 \\
\hline Autonomy & 0.40 & $.29^{* * *}$ & 0.58 & $.35^{* * *}$ & 0.60 & $.39^{* * *}$ \\
\hline Variety & 0.35 & $.20^{* *}$ & 0.52 & $.24^{* * *}$ & 0.47 & $.23^{* * *}$ \\
\hline$\Delta R^{2}$ & & $.13^{* * *}$ & & $.17^{* * *}$ & & $.20^{* * *}$ \\
\hline \multicolumn{7}{|l|}{ Step 3: Interactions } \\
\hline Workload x Autonomy & -0.09 & -.03 & 0.20 & .06 & 0.04 & .01 \\
\hline Workload x Variety & 0.21 & $.11^{\dagger}$ & 0.20 & .08 & 0.17 & .08 \\
\hline Autonomy x Variety & 0.31 & $.14^{*}$ & 0.12 & .04 & 0.01 & .00 \\
\hline$\Delta R^{2}$ & & $.02^{*}$ & & .01 & & .01 \\
\hline Total $R^{2}$ & \multicolumn{2}{|c|}{.19} & \multicolumn{2}{|c|}{.20} & \multicolumn{2}{|c|}{.28} \\
\hline
\end{tabular}

${ }^{\dagger} p<.10,{ }^{*} p<.05,{ }^{* *} p<.01,{ }^{* * *} p<.001$

\section{Discussion}

The present study focused on antecedents of work flow dimensions among higher education teachers. An important preliminary issue of our study was also to establish the factorial validity of the Slovenian version of the WOLF scale. The proposed relations between job resources (i.e., autonomy and variety) and the work-related flow dimensions were generally confirmed. More precisely, autonomy and variety were positively related to absorption, work enjoyment and intrinsic work motivation. Autonomy was found to be the most important predictor of all the work-related flow dimensions. The later findings are consistent with previous research (Bakker, 2005, 2008; Fried and Ferris, 1987; Saavedra and Kwun, 2000). These results suggest how important it is for employees to have the freedom to schedule their work and to

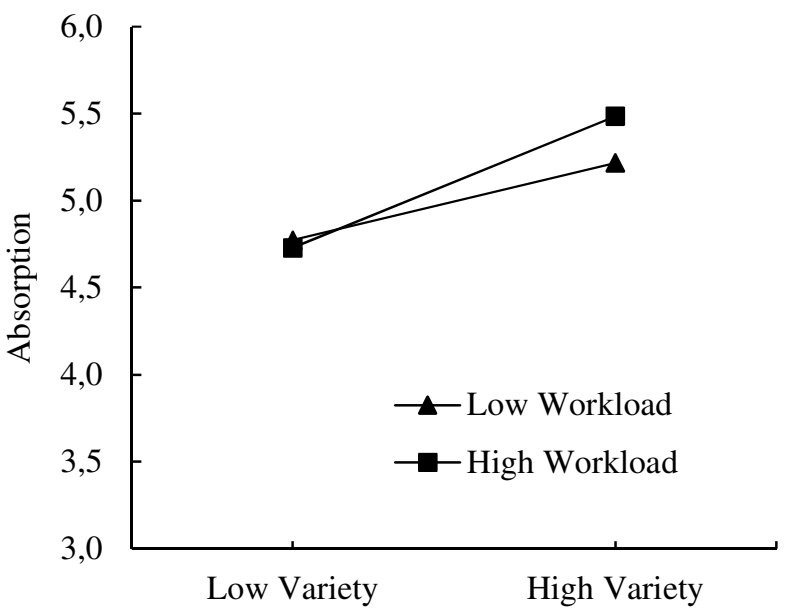

Figure 1. The interactive effect of variety and workload on absorption. determine ways to execute work tasks in order to experience work flow. As we have already mentioned, variety also increases work flow (Demerouti, 2006). That means that in order to enhance work flow, it is important to be able to experience a diversity of work activities that require different skills and talents from the employee.

Workload, on the other hand, was not significantly related to any of the outcomes. So our fourth hypothesis, predicting that workload will be negatively related to all the three dimensions of workflow, was rejected. Although not significantly, workload was positively related to absorption. The correlation, on the other hand, was positive and significant. Such findings could imply that workload may contribute to a higher absorption, whereas enjoyment and intrinsic work motivation can be diminished. Similar findings were obtained in a longitudinal study, where time

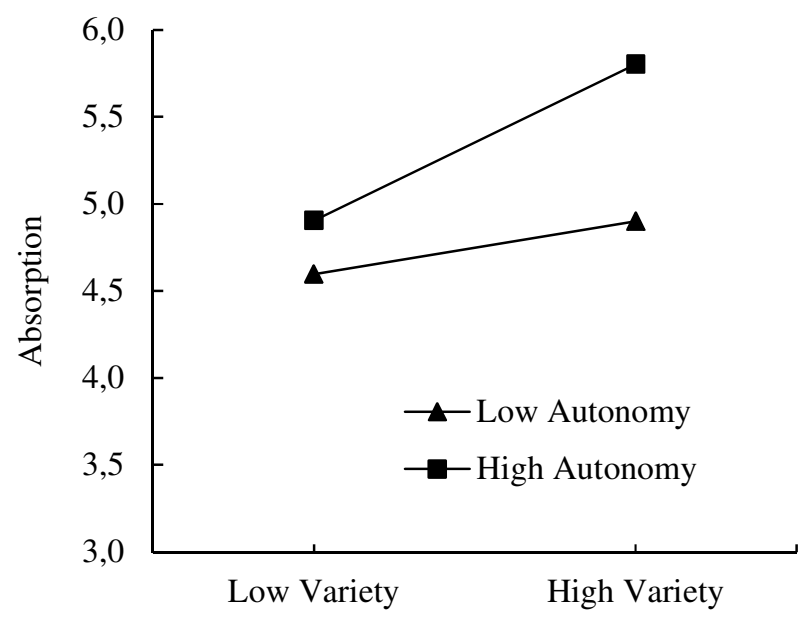

Figure 2. The interactive effect of variety and autonomy on absorption. 
pressures at work were positively related to the long-term absorption aspect of work engagement (Mauno, Kinnunen, \& Ruokolainen, 2007). Apparently, workload could also operate as a motivation-promoting job characteristic. In other terms, workload may represent a challenge demand related to personal growth and achievement (in contrast to a hindrance demands; Podsakoff, LePine, \& LePine, 2007).

Interactive effects were found between variety and autonomy as well as variety and workload when predicting absorption. Higher variety was related to higher absorption regardless of autonomy levels. However, in the condition of high autonomy, greater variety levels substantially increased absorption levels. When examining the interaction between variety and workload, higher variety was related to higher absorption per se. In addition, the results also indicate that under conditions of high workload and high variety, feelings of absorption are even more likely to occur. The first result could be interpreted in the light of the motivational potential score (Hackman \& Oldham, 1975) where autonomy and variety are valued in their own right and both add to the motivational potential of a job. The second result may be more in line with the DCM model (Karasek, 1979) and the notional of "active jobs". It also extends the findings of Fagerlind et al. (2013) by obtaining similar results among university teachers from another country.

A note should also be given to our results regarding the control variables (gender, academic rank and age). Women and teachers with higher ranks experienced more absorption and intrinsic work motivation, respectively. Such findings are not surprising considering the fact that teachers with higher ranks also have higher job autonomy and a more resourceful work setting in general. Gender differences can be partially explained by the fact that women tend to experience positive emotional states in a more intensive and vivid way (Fujita, Diener, \& Sandvik, 1991). We may assume that the same might hold true for women when making evaluations of the work setting, its demands and resources.

\section{Study strengths, limitations and implications}

Our study has several strengths. It is the first study of work-related flow that has been conducted in Slovenia and one of the very few studies about flow among higher education teachers. It further closes an important gap by examining also interactive effects of different antecedents (i.e., job resources and demands) when predicting flow. On a minor note, the study also provides the first evidence on reliability and factorial validity of the Slovenian version of the work-related flow scale.

However, our study has some limitations, which should be considered when generalizing the results of the present study. The principal limitation concerns sampling and response rate. The sample might be biased because employees with more work-related flow are usually more intrinsically motivated and therefore more prone to take part also in the research of other colleagues. The low response could pose a threat for the generalizability of the findings. However, the gender distribution in our sample is not notably different from the overall registered number of higher education teachers in Slovenia (42.9\% of women among Slovenian higher education teachers; Statistical Office of the Republic of Slovenia, 2015). The same holds true for age and academic rank $34.1 \%$ of university employees of lower academic rank; $20 \%$ of higher education teachers are aged 60 or more; Statistical Office of the Republic of Slovenia, 2015).

The second limitation is that we assessed flow using (retrospective) self-report data, which are prone to response styles, personality characteristics and affective states (e.g., Bakker, 2008). It would be advisable to use the experiencesampling procedure, where employees are asked to fill out a short questionnaire with their feelings and experiences during random moments of the day (Csíkszentmihályi, 2002). However, it should be noted that retrospective self-report questionnaires are applied in the majority of studies on workrelated flow. Another argument in favor of retrospective self-reports was pointed out by Bakker (2008), who claimed that it is technically not possible yet to measure flow while it happens. Future studies should, however, could consider applying a longitudinal design in order to examine stability and change in work-related flow over time (Mäkikangas, Bakker, Aunola, \& Demerouti, 2010).

Also with the upper recommendations, future studies should also use a wider range of job characteristics. Examining resources such as performance feedback or task significance could be a promising research step. It would also be advisable to distinguish between personal and organizational resources. The former represent positive self-evaluations and are linked to resilience (Salanova et al., 2006). Therefore, they may be important for diminishing demands, stimulating personal growth, and in turn for enhancing flow. Self-efficacy and optimism are potential examples which can be explored in future studies.

\section{Conclusions}

It is important for higher education teachers themselves, as well as for the university management, to know which means can be used to sustain employees' work flow. Our study shows that workload by itself does not diminish work flow. In fact, support was found for a motivation-promoting role of workload. However, different job resources play a far more important role. Autonomy and variety were found to enhance absorption, work enjoyment and intrinsic work motivation. Based on this, higher education teachers should consider how to increase their own autonomy and job variety. Intentionally crafting the job towards taking over new assignments (e.g., teaching a new course), setting more challenging work goals (e.g., publishing an article in SSCI highest ranking journals) or asking for new self-managed responsibilities (e.g., being a student's advisor) could be promising ways to enhance work flow and consequently job productivity. Such self-management techniques could be particularly useful for those experiencing the lowest work-related flow levels (i.e., male professors, and teachers with lower academic ranks). However, it should be noted that interventions towards more challenging jobs must also derive from university management. 


\section{References}

Aguinis, H. (1995). Statistical power problems with moderated multiple-regression in management research. Journal of Management, 21, 1141-1158.

Aiken, L. S., \& West, S. G. (1991). Multiple regression: Testing and interpreting interactions. Thousand Oaks, CA, USA: Sage Publications.

Aryee, S., Srinivas, E. S., \& Tan, H. H. (2005). Rhythms of life: Antecedents and outcomes of work-family balance in employed parents. Journal of Applied Psychology, 90, 132-146.

Bakker, A. B. (2005). Flow among music teachers and their students: The crossover of peak experiences. Journal of Vocational Behavior, 66, 26-44.

Bakker, A. B. (2008). The work-related flow inventory: Construction and initial validation of the WOLF. Journal of Vocational Behavior, 72, 400-414.

Bakker, A. B., \& Demerouti, E. (2007). The job demandsresources model: State of the art. Journal of Managerial Psychology, 22, 309-328.

Bakker, A. B., \& Demerouti, E. (2008). Towards a model of work engagement. Career"Development International, 13, 209-223.

Bakker, A. B., Hakanen, J. J., Demerouti, E., \& Xanthopoulou, D. (2007). Job resources boost work engagement, particularly when job demands are high. Journal of Educational Psychology, 9, 9-16.

Beard, K.S., \& Hoy, W.K. (2010). The nature, meaning, and measure of teacher flow in elementary schools: A test of rival hypotheses. Educational Administration Quarterly, 46(3), 426-458.

Boyar, S. L., Carr, J. C., Mosley, D. C., Jr., \& Carson, C. M. (2007). The development and validation of scores on perceived work and family demand scales. Educational and Psychological Measurement, 67, 100-115.

Brown, T. A. (2006). Confirmatory factor analysis for applied research. New York, NY, USA: Guilford Press.

Cook, C., Heath, F., \& Thompson, R. (2000). A meta-analysis of response rates in web-or internet-based surveys. Educational and Psychological Measurement, 60, 821-836.

Csíkszentmihályi, M. (2002). Flow: The classic work on how to achieve happiness. London, United Kingdom: Rider.

Deci, E. L., \& Ryan, R. M. (1985). Intrinsic motivation and self-determination in human behavior. New York, NY, USA: Plenum Press.

Demerouti, E. (2006). Job characteristics, flow, and performance: The moderating role of conscientiousness. Journal of Occupational Health Psychology, 11, 266-280.

Fagerlind, A. C., Gustavsson, M., Johansson, G \& Ekberg, K. (2013). Experience of work-related flow: Does high decision latitude enhance benefits gained from job resources? Journal of Vocational Behavior, 83, 161-170.

Fried, Y., \& Ferris, G. R. (1987). The validity of the job characteristics model: A review and a meta-analysis. Personnel Psychology, 40, 287-322.
Fujita, F., Diener, E., \& Sandvik, E. (1991). Gender differences in negative affect and well-being: The case for emotional intensity. Journal of Personality and Social Psychology, 61, 427-434.

Hackman, J. R., \& Oldham, G. R. (1975). Development of the job diagnostic survey. Journal of Applied Psychology, 60, 159-170.

Halbesleben, J. R. B. (2010). A meta-analysis of work engagement: Relationships with burnout, demands, resources, and consequences. In A. Bakker \& M. P. Leiter (Eds.), Work engagement: A handbook of essential theory and research (pp. 102-117). New York, NY, USA: Psychology Press.

Jackson, S., \& Csíkszentmihályi, M. (1999). Flow in sport: The keys to optimal experiences and performances. Urbana, IL, USA: Human Kinetics.

Jackson, S. A., Kimiecik, J. C., Ford, S. K., \& Marsh, H. W. (1998). Psychological correlates of flow in sport. Journal of Sport and Exercise Psychology, 20, 358-378.

Karasek, R. A. (1979). Job demands, job decision latitude, and mental strain: Implications for job redesign. Administrative Science Quarterly, 24, 285-308.

Karasek, R. A. (1998). The new work organization conductive production and work quality policy. In M. Marmot (Ed.), Labor market changes and job insecurity: A challenge for social welfare and health promotion (pp. 78-105). Copenhagen, Denmark: WHO /Europe.

Karasek, R. A., Brisson, C., Kawakami, N., Houtman, I., Bongers, P., \& Amick, B. (1998). The Job Content Questionnaire (JCQ): An instrument for internationally comparative assessment of psychosocial job characteristics. Journal of Occupational Health Psychology, 3, 322-355.

Košir, K., \& Kos Strašek, T. (2015). Kontekstualni dejavniki spodbujanja avtonomije učencev pri učiteljih osnovne in srednje šole [Contextual factors promoting the autonomy of pupils by teachers of primary and secondary schools]. Revija za elementarno izobraževanje, 8(4), 49-64.

Košir, K., Licardo, M., Tement, S., \& Habe, K. (2014). Doživljanje stresa in izgorelosti, povezanih $\mathrm{z}$ delom $\mathrm{Z}$ učenci s posebnimi potrebami pri učiteljih v osnovni šoli [Stres and burnout related to work with special education needs students in elementary school teachers]. Psihološka obzorja, 23, 110-124.

Mauno, S., Kinnunen, U., \& Ruokolainen, M. (2007). Job demands and resources as antecedents of work engagement: A longitudinal study. Journal of Vocational Behavior, 70, 149-171.

Mäkikangas, A., Bakker, A. B., Aunola, K., \& Demerouti, E. (2010). Job resources and flow at work: Modelling the relationship via latent growth curve and mixture model methodology. Journal of Occupational and Organizational Psychology, 83, 795-814.

McDonald, R. P., \& Ho, M. H. R. (2002). Principles and practice in reporting structural equation analyses. Psychological Methods, 7, 64-82.

O'Neill, S.A. (1999). Flow theory and the development of musical performance skills. Bulletin of the Council for Research in Music Education, 141, 129-134. 
Podsakoff, N. P., LePine, J. A., \& LePine, M. A. (2007). Differential challenge stressor-hindrance stressor relationships with job attitudes, turnover intentions, turnover, and withdrawal behavior: A meta-analysis. Journal of Applied Psychology, 92, 438-454.

Quinn, R. V. (2005). Flow in knowledge work: High performance experience in the design of national security. Administrative Science Quarterly, 50, 610-641.

Saavedra, R., \& Kwun, S. K. (2000). Affective states in job characteristics theory. Journal of Organizational Behavior, 21, 131-146.

Salanova, M., Bakker, A. B., \& Llorens, S. (2006). Flow at work: Evidence for an upward spiral of personal and organizational resources. Journal of Happiness Studies, 7, 1-22.

Statistical Office of the Republic of Slovenia. (2015). Instructional and professional support staff at higher education institutions and vocational colleges, Slovenia, 2014. Retrieved from http://www.stat. si/StatWeb/en/show-news?id=5553\&idp=9\&headerbar $=5$

Tement, S., \& Korunka, C. (2013). Does trait affectivity predict work-to-family conflict and enrichment beyond job characteristics? The Journal of Psychology: Interdisciplinary \& Applied, 147, 197-216.

Wanous, J. P., \& Hudy, M. J. (2001). Single item reliability: A replication and extension. Organizational Research Methods, 4, 361-375.

Wanous, J. P., Reichers, A. E., \& Hudy, M. J. (1997). Overall job satisfaction: How good are single-item measures? Journal of Applied Psychology, 82, 247-252. 